\title{
Insulin-Degrading Enzyme: Paradoxes and Possibilities
}

\author{
Malcolm A. Leissring (D)
}

check for

updates

Citation: Leissring, M.A.

Insulin-Degrading Enzyme:

Paradoxes and Possibilities. Cells

2021, 10, 2445. https://doi.org/

10.3390/cells10092445

Academic Editor:

Victoriano Baladrón

Received: 24 August 2021

Accepted: 14 September 2021

Published: 16 September 2021

Publisher's Note: MDPI stays neutral with regard to jurisdictional claims in published maps and institutional affiliations.

Copyright: (c) 2021 by the author. Licensee MDPI, Basel, Switzerland. This article is an open access article distributed under the terms and conditions of the Creative Commons Attribution (CC BY) license (https:/ / creativecommons.org/licenses/by/ $4.0 /)$.
Institute for Memory Impairments and Neurological Disorders, University of California, Irvine (UCI MIND), Irvine, CA 92697, USA; m.leissring@uci.edu

\begin{abstract}
More than seven decades have passed since the discovery of a proteolytic activity within crude tissue extracts that would become known as insulin-degrading enzyme (IDE). Certainly much has been learned about this atypical zinc-metallopeptidase; at the same time, however, many quite fundamental gaps in our understanding remain. Herein, I outline what I consider to be among the most critical unresolved questions within the field, many presenting as intriguing paradoxes. For instance, where does IDE, a predominantly cytosolic protein with no signal peptide or clearly identified secretion mechanism, interact with insulin and other extracellular substrates? Where precisely is IDE localized within the cell, and what are its functional roles in these compartments? How does IDE, a bowl-shaped protein that completely encapsulates its substrates, manage to avoid getting "clogged" and thus rendered inactive virtually immediately? Although these paradoxes are by definition unresolved, I offer herein my personal insights and informed speculations based on two decades working on the biology and pharmacology of IDE and suggest specific experimental strategies for addressing these conundrums. I also offer what I believe to be especially fruitful avenues for investigation made possible by the development of new technologies and IDE-specific reagents. It is my hope that these thoughts will contribute to continued progress elucidating the physiology and pathophysiology of this important peptidase.
\end{abstract}

Keywords: diabetes mellitus; insulin; insulin-degrading enzyme; proteolysis; protease inhibitors

\section{Introduction}

Biology is a curious mixture of science and art. On the one hand, X-ray crystallography can reveal the 3-dimensional structure of a particular protein in exquisite detail, right down to the atomic scale-reductionistic science par excellence. On the other hand, divining the functional role(s) of that protein more typically involves inference, intuition, and even guesswork-more like detective work than science-and decades can pass before complete elucidation of the protein's physiological function(s). Such is the case for insulin-degrading enzyme (IDE; a.k.a. insulinase, insulysin; EC 3.4.24.56), an atypical zinc-metallopeptidase first described in 1949 [1,2], for which the crystal structure was obtained in 2006 [3,4]. In this commentary, I outline and discuss several outstanding questions about the biology and enzymology of IDE that warrant further elucidation, many of which take the form of intriguing paradoxes. By bringing these puzzling aspects into greater relief, I hope to identify lacunae in our understanding of the biology of IDE into which future research might shed new light.

\section{Is IDE the Insulin-Degrading Enzyme?}

IDE was first identified by I. Arthur Mirsky and colleagues by searching for a proteolytic activity capable of degrading insulin within crude extracts from tissues such as liver $[1,2]$. The designation of IDE as a peptidase of insulin specifically-rather than any other substrate, such as glucagon, amylin or amyloid $\beta$-protein $(A \beta)$ - has had the effect of coloring our conception of its functional role ever since. Having been designated "the insulin-degrading enzyme," it was natural to assume that IDE mediates insulin clearance in vivo. Subsequent research would show that IDE is ubiquitously expressed in both 
insulin-sensitive and -nonsensitive cells, where it is located primarily in the cytosol [5], basic facts in stark conflict with an exclusive role in insulin clearance, and yet this assumption held strong. Seventy-two years on; however, despite a few early animal studies reported findings consistent with this basic idea [6-9], there is now a growing body of evidence that casts doubt on this long-held assumption—or, at a minimum, offers compelling reasons to conclude that IDE mediates several other processes besides insulin clearance. The conflicting evidence was recently extensively reviewed [5,10], but the more glaring inconsistencies include a study from Eli Lilly reporting that a potent and selective IDE inhibitor they developed had no effect on insulin action in vivo as measured by euglycemic clamping (despite improving glucose tolerance) and, moreover, no effect on degradation of exogenous insulin in cultured cells [11]. In addition, genetic deletion of IDE in liver, the principal site of insulin clearance, failed to slow the clearance of circulating insulin [12], as IDE's name would suggest; instead, rather paradoxically, overexpression of IDE in liver was found to reverse a diabetic phenotype induced by a high-fat diet [13]. Finally, the discovery that IDE appears to play a key role in —of all things-insulin secretion $[14,15]$ is yet another beguiling rebuttal to long-held assumptions about IDE's physiological function. As discussed more extensively in a recent review [5], these and many other observations suggest that Mirsky's original idea that pharmacological inhibition of IDE could be used to treat type 2 diabetes (by slowing insulin clearance $[16,17]$ ) - though certainly worthy of investigation - may need to be reconsidered (or at least refined) in the light of what we have learned about IDE in the intervening decades.

Thus, in my view, the name "insulin-degrading enzyme" has led the field astray. It is probably too late to change it, but a name lacking the word "insulin" would certainly help temper long-unquestioned assumptions about its function (perhaps "mesopeptidase" to distinguish it from exopeptidases, oligopeptidases, and proteases). At the very least, those of us in the field, and especially those entering it, ought to be advised to appreciate that IDE's functions extend beyond insulin degradation — and, indeed, may perhaps have surprisingly little to do with it in vivo.

\section{Where Is IDE?}

Another discomfiting reality for the IDE field is persistent uncertainty about its subcellular localization. The vast majority of IDE is unquestionably present in the cytosol; IDE harbors no signal peptide [18] and is not secreted via the classical protein secretion pathway [19-22]. Consistent with a cytosolic localization, the peptidase appears to have no posttranslational modifications apart from acetylation of the N-terminus [23]. There is also definitive evidence for the presence of IDE within mitochondria. Alternative translation initiation of the Ide mRNA results in the addition of a 41-amino acid mitochondrial targeting sequence [24]. Expression of the mitochondrial isoform is limited, however, by the fact that the upstream initiation codon does not contain a strong Kozak consensus sequence [24,25]. Seemingly quite convincing evidence suggests that IDE is targeted to peroxisomes, as well [26]. The C-terminus of IDE ends in AKL, a tripeptide consistent with a type 1 peroxysomal targeting sequence (PTS1). More recently, however, the entirety of the PTS1 was shown to consist of 12 C-terminal amino acids [27], not just 3, and modern bioinformatic programs, such as The PTS1 Predictor [28], conclude that IDE is unlikely to be targeted to peroxisomes. Given this, there seems sufficient reason to re-examine whether this signal is a valid PTS1 or not. Finally, IDE was reported to be localized within endosomes [29-33] as well as associated with the plasma membrane [34-38]. However, much of the underlying evidence is decades old and frankly of mixed quality; moreover, some well-controlled studies have found no evidence for localization within either compartment, nor within lysosomes (e.g., [26]). Some of these contradictory findings may be explained if the subcellular localization of IDE is cell-type specific, but the possibility of contamination by mitochondrial (or peroxisomal) IDE even in the most carefully performed subcellular fractionation studies cannot be entirely excluded. 
In a similar vein, the idea that IDE is present extracellularly seems well established, but precisely how IDE might be trafficked to the extracellular space remains obscure. For example, IDE was identified as the major protease responsible for degrading A $\beta$, a secreted peptide, in the conditioned medium of various cell types [39-42]. Moreover, genetic deletion of IDE increases [6,43-45] and overexpression decreases [46] levels of cerebral $\mathrm{A} \beta$ in vivo, consistent with the idea that IDE is present within the extracellular interstitial fluid in the brain (or one or more topographically contiguous subcellular compartments). Some groups have reported that IDE might be secreted from different cell types by various non-conventional export pathways [20,21,47], while other groups, such as Eli Lilly, simply found no evidence for extracellular IDE in cultured cells [11].

Could the "secretion" of IDE-particularly from cultured cells—represent non-specific spillage and/or basal turnover of cytosolic contents? Consistent with this view, Hersh and colleagues conducted a careful study that found that IDE secretion from multiple cultured cell lines tracked perfectly with generic markers of cytosolic proteins, such as lactose dehydrogenase (LDH) [19]. Similarly, in an unpublished cell-based compound screening campaign of $\sim 1.2$ million drug-like molecules, which monitored IDE activity and LDH release in parallel, my group found that all compounds that increased extracellular IDE activity also increased LDH release (M. L. unpublished observations).

In my opinion, the field needs to revisit the questions of where in the cell IDE is located, whether it is secreted and, if so, precisely how. Rather than relying exclusively on published reports, most several decades old and some using less-than-ideal methodologies, we should make full use of the powerful new tools now available, such as IDE-null cells $[6,8]$, multiple monoclonal antibodies [48], and IDE-specific molecular probes [9,49-52], which should be deployed in tandem with modern labeling and imaging techniques. As for the secretion of IDE, I believe more in vivo studies are needed to verify whether IDE is (ordinarily) present extracellularly and, if so, to what extent. Current evidence for IDE within plasma [20,21,53-55] is largely indirect, often relying upon antibody capture approaches coupled with activity assays (which have their own problems; see below). Using physiological levels of radiolabeled peptides, my own group found vanishingly little $A \beta$ - or insulin-degrading activity in neat, EDTA-free plasma, and we also found an underwhelming amount of $A \beta$-degrading activity sensitive to IDE-specific inhibitors in CSF (M. L. unpublished observations). It may be that IDE is secreted but nonetheless relatively inactive in plasma and CSF, due to specific or non-specific endogenous inhibitors, in which case immunoprecipitation experiments would be particularly appropriate. These topics are of paramount significance to the field, particularly to many long-held assumptions within it, and thus are deserving of being intensively investigated anew.

\section{Enzymological Paradoxes and Problems}

Numerous X-ray crystallographic and cryo-electron microscopic studies of IDE have now been conducted [4,56-58], revealing that IDE exists as a homodimer, with each unit being comprised of two bowl-shaped halves connected by a linker, resembling a clamshell. Each monomer can adopt "open" and "closed" conformations, completely encapsulating a large internal chamber when "closed" [4,58]. Notably, the active site is bipartite, with portions present in both the $\mathrm{N}$ - and C-terminal halves, becoming fully functional only in the "closed" conformation, and accessible exclusively from within the internal chamber $[4,56,59]$. This distinctive structure explains several previously puzzling properties of IDE. For instance, because substrates must fit entirely within the internal chamber to be processed, this explains why IDE can only degrade peptides while being unable to process proteins. Moreover, because substrates make extensive contacts throughout the internal chamber, including at multiple sites distal to the active site, this explains IDE's otherwise baffling substrate specificity, such as how IDE avidly degrades IGF II, for example, but only slowly degrades similarly sized, related substrates such as IGF I [60-62]. The extensive and variable contacts made between different substrates and IDE also help explain why small-molecule modulators of IDE frequently show striking substrate-specific 
differences in potency; indeed, compounds that activate the degradation of some substrates can actually inhibit the degradation of others $[49,63]$. Most recently, this peculiar property has been quite usefully exploited to develop insulin-specific inhibitors of IDE [50].

At the same time, IDE's peculiar structure also raises several intriguing paradoxes. For example, what prevents IDE from becoming quickly and hopelessly "clogged up" by any of the myriad peptides and other intermediate-sized molecules in its vicinity? Just considering its known substrates, IDE has been shown to form stable, irreversible complexes with both $\mathrm{A} \beta[64,65]$ and $\alpha$-synuclein $[66,67]$. Even highly purified, extensively washed, recombinant IDE used for crystallization experiments has invariably been found to contain non-specific peptides within its internal chamber [56]. Some have proposed that this feature of IDE may reflect a "dead-end chaperone" function, possibly serving to sequester amyloidogenic peptides $[15,65,67]$. Perhaps. However, if this occurs for some peptides, it likely occurs for many more. My question is: what keeps IDE from getting clogged? I believe this is a genuine conundrum deserving, at a minimum, of further research and, ultimately, of a mechanistic explanation.

Another, potentially related question exists: if IDE exists predominantly in the "closed" conformation, as most crystal structures show and other evidence suggests [56,57], what triggers the transition to the "open" conformation? Inter-subunit cooperativity may provide part of the explanation, with the action of one subunit affecting the other allosterically [68], and recent cryo-electron micrographic studies seem consistent with this idea [58]. Nevertheless, it is intriguing to ask: what if anything causes IDE to open? Can substrates participate in this process?

There is also the curious fact that there seems to be an uncannily snug fit between insulin and IDE's internal chamber $[4,58,69]$ — could there be a functional significance to this or is it mere coincidence? Here, I offer a speculative but intriguing possibility: perhaps the binding of insulin to IDE could serve as a signal of sorts-i.e., an indicator of the presence of insulin - transmitted to other cellular components in turn via a conformational change, for example. Such a signaling event might even occur in the cytosol, given the considerable (and surprising) literature suggesting that insulin can in fact reach the cytosol and even the nucleus [70-75]. In this admittedly highly speculative scenario, hydrolysis of insulin by IDE would constitute a mechanism for resetting the signaling mechanism to the initial state.

In concluding this section on enzymological properties of IDE, I would like to make a sincere appeal to those in the field: please stop using short fluorogenic peptide substrates to monitor IDE activity. These substrates are ill-suited for multiple reasons. First, they are prone to degradation by numerous off-target proteases and to that extent are ill-suited for applications with biological materials (unless IDE-specific inhibitors are used to distinguish IDE activity from non-IDE activity). Second, the processing of such short peptides by IDE differs in significant ways from the processing of larger substrates. By virtue of their larger size, physiological IDE substrates such as insulin and amylin interact with a distal exosite, which appears to be critical for substrate recognition and processing [76]. Shorter substrates, by contrast, do not [77]. As a consequence, when used for compound screening or in vitro activity assays, short fluorogenic peptides frequently lead to the identification of "activators" that prove to be nothing of the kind when tested against more physiological substrates $[63,78]$. In my considered opinion, these compounds "activate" IDE for a trivial reason: they occupy a portion of the internal chamber of IDE, therefore reducing the remaining volume available to the short fluorogenic peptide and in this way, increasing the likelihood of making fruitful contact with the active site of IDE. While it may one day be possible to identify bona fide IDE activators, the search needs to be conducted with physiological substrates, not fluorogenic peptides-and so far my own laboratory's efforts to identify activators using this approach, including testing 2 million compounds in multiple compound screening campaigns, were unsuccessful (M. L. unpublished observations). Precisely to overcome the limitations of short fluorogenic substrates, and to facilitate these screens, my laboratory expended considerable efforts developing several 
well-characterized and highly quantitative assays for multiple physiological substrates of IDE [79-81]. Given the availability of these considerably more reliable IDE activity assays, which use inexpensive reagents and can be readily implemented by any laboratory equipped with a fluorometer, there is, in my opinion, no justifiable reason to rely on short fluorogenic peptides when seeking to quantify IDE activity.

\section{IDE Partners?}

Does IDE primarily exist as a free-floating, self-sufficient, homodimeric protein, operating in isolation? This view does indeed seem supported by several facts, including the high activity of purified recombinant IDE, the fact that it is found predominantly within the soluble fraction of cells, while also being secreted. However, over the years, IDE has been suggested to interact with a variety of components, including the androgen receptor [82], the proteasome [83-85], certain membrane associated phosphoinositides [86], among others (reviewed in [5]). However, some of these interactions were merely postulated and others not confirmed by independent groups.

I feel strongly that the field would benefit significantly from a thorough search for potential partners of IDE, proteinaceous or otherwise. Protein partners and/or new substrates might be discovered via many possible methodologies, including in vitro transcription/translation approaches with immobilized IDE, co-immunoprecipitation experiments with anti-IDE monoclonal antibodies coupled with mass spectrometric analyses, and/or by approaches using reversible crosslinking agents. Biotinylated versions of IDE-selective probes of IDE, such as $6 \mathrm{bK}$ [9] or even insulin, could also be exploited to search for both proteinaceous and non-proteinaceous interacting partners. In contrast to earlier decades, numerous, very powerful technologies are available to the modern researcher, and a thorough search IDE-interacting partners could very possibly lead to fruitful discoveries of great importance to the field.

\section{Possibilities}

Thanks to recent advances both within the IDE field and in biology generally, many exciting possibilities for future investigation are now available, which have-rather surprisingly-remained relatively unexplored. Some of these opportunities hold great promise for helping to resolve the longstanding paradoxes discussed above, while others may open new avenues of investigation and/or new therapeutic advances.

Many of the most exciting new possibilities hinge on the development of powerful pharmacological modulators of IDE. It needs to be emphasized that until 2010-more than 60 years after the discovery of IDE-there were literally no selective pharmacological inhibitors of IDE or any member of its unusual peptidase superfamily [87]. Since that time, numerous inhibitors were developed that are: (1) potent and selective for IDE [9,11,50,51,87-89]; (2) in vivo compatible [11,52,89]; (3) selective for extracellular IDE exclusively [52,90]; (4) inexpensive to synthesize [49,51]; and (5) substrate selective [88,91,92], with many compounds with multiple meritorious properties simultaneously. These IDE inhibitors represent a powerful yet essentially untapped resource for the field, which could be used to address numerous topics. In this regard, it is important to emphasize that both proteolytic and non-proteolytic functions were assigned to IDE [5,93]. Up to this point; however, most manipulations of IDE have been limited to genetic deletion or overexpression, which modifies not just the activity but also the protein itself. Studies conducted with pharmacological inhibitors, by contrast, would permit the proteolytic activity of IDE to be interrogated while leaving the protein itself unperturbed, which may yield fresh insights into IDE's function. IDE inhibitors might also be useful for clarifying precisely where IDE exists within cells: in a simplistic example, if IDE exists in endosomes, then extracellular application of non cell-penetrant compounds (or those active extracellularly only [52]) should effectively block IDE activity within endosomes (and the extracellular space), while sparing IDE activity in other cellular compartments. Additionally, the newly developed inhibitors can be used to explore the therapeutic potential of IDE inhibition in domains 
besides diabetes, such as wound healing [94-96], as made possible by the invention of cost-effective peptidic IDE inhibitors [51]. Last but not least, the development of an insulinspecific IDE inhibitor by Liu and colleagues [50] is an extraordinary achievement that at long last permits us to explore IDE's impact on insulin independent of the confounding effects of other IDE substrates that complement or counteract insulin action (e.g., amylin, glucagon). This very exciting new class of inhibitor has immediate potential for elucidating the exact relationship(s) between IDE and insulin signaling in cultured cells and ex vivo tissue culture and-perhaps after suitable modification — might eventually be used to help clarify IDE's role(s) in insulin homeostasis in vivo.

The relatively recent development of genetically modified mouse lines permitting inducible and tissue-specific genetic deletion of IDE has helped significantly advance the field, while at the same time raising new questions about IDE's physiological functions $[10,12-14]$. More studies of this kind seem warranted. In particular, longitudinal studies that follow the consequences of inducible deletion of IDE-triggered after development, either throughout the body or in specific tissues or cell types-would be especially illuminating, because they could help distinguish primary consequences of IDE deletion from secondary ones, which may include confounding compensatory changes [10].

The advent of powerful new gene-modifying technologies, such as CRISPR-Cas9 [97], also opens up fresh avenues for experimental investigation. The significance of the mitochondrial variant of IDE, for instance, could be investigated readily by inserting a point mutation at the upstream initiation codon that precludes translation of the mitochondrial targeting sequence (or conversely, by mutating the downstream initiation codon to preclude non-mitochondrial variants) [24]. The putative PTS1 signal at the C-terminus of IDE could be interrogated similarly. In addition to (or rather than) generating novel mouse lines, these exciting technologies could also be used to generate pluripotent stem cells, which could then be tested in cell culture after differentiation into different cell types. A complementary cell culture approach would be to generate immortalized cell lines lacking IDE, then express different variants of IDE-such as fluorescently tagged versions-in these IDE-null cells to investigate various topics.

\section{Conclusions}

In summary, I sought herein to illuminate a few of the more puzzling aspects surrounding the biology and pharmacology of IDE, as well as to point out a few relatively untapped possibilities for future research. I hope this might help in some small way to inspire previously unconsidered research directions, which in turn may help resolve some of the many paradoxes within the field. IDE is an important peptidase with strong links to several human diseases, so resolving these outstanding questions will expand our understanding of these disorders and, potentially, could lead to novel therapeutic approaches.

Funding: This research was funded by the National Institutes of Health, grant numbers R01GM115617, R21GM140283 and R01AG066928.

Acknowledgments: I thank Shelley Lane for critical reading of the manuscript.

Conflicts of Interest: The author declares no conflict of interest.

\section{References}

1. Mirsky, I.A.; Broth-Kahn, R.H. The inactivation of insulin by tissue extracts. I. The distribution and properties of insulin inactivating extracts (insulinase). Arch. Biochem. 1949, 20, 1-9.

2. Simkin, B.; Broh-Kahn, R.H.; Mirsky, I.A. The inactivation of insulin by tissue extracts; the effect of force-fed diets on the insulinase activity of rat liver extracts. Arch. Biochem. 1949, 24, 422-428.

3. Leissring, M.A.; Selkoe, D.J. Enzyme target to latch on to. Nature 2006, 443, 761-762. [CrossRef]

4. Shen, Y.; Joachimiak, A.; Rosner, M.R.; Tang, W.J. Structures of human insulin-degrading enzyme reveal a new substrate recognition mechanism. Nature 2006, 443, 870-874. [CrossRef]

5. Leissring, M.A.; Gonzalez-Casimiro, C.M.; Merino, B.; Suire, C.N.; Perdomo, G. Targeting insulin-degrading enzyme in insulin clearance. Int. J. Mol. Sci. 2021, 22, 2235. [CrossRef] [PubMed] 
6. Farris, W.; Mansourian, S.; Chang, Y.; Lindsley, L.; Eckman, E.A.; Frosch, M.P.; Eckman, C.B.; Tanzi, R.E.; Selkoe, D.J.; Guenette, S. Insulin-degrading enzyme regulates the levels of insulin, amyloid beta-protein, and the beta-amyloid precursor protein intracellular domain in vivo. Proc. Natl. Acad. Sci. USA 2003, 100, 4162-4167. [CrossRef] [PubMed]

7. Farris, W.; Mansourian, S.; Leissring, M.A.; Eckman, E.A.; Bertram, L.; Eckman, C.B.; Tanzi, R.E.; Selkoe, D.J. Partial loss-offunction mutations in insulin-degrading enzyme that induce diabetes also impair degradation of amyloid beta-protein. Am. J. Pathol. 2004, 164, 1425-1434. [CrossRef]

8. Abdul-Hay, S.O.; Kang, D.; McBride, M.; Li, L.; Zhao, J.; Leissring, M.A. Deletion of insulin-degrading enzyme elicits antipodal, age-dependent effects on glucose and insulin tolerance. PLoS ONE 2011, 6, e20818. [CrossRef]

9. Maianti, J.P.; McFedries, A.; Foda, Z.H.; Kleiner, R.E.; Du, X.Q.; Leissring, M.A.; Tang, W.J.; Charron, M.J.; Seeliger, M.A.; Saghatelian, A.; et al. Anti-diabetic activity of insulin-degrading enzyme inhibitors mediated by multiple hormones. Nature 2014, 511, 94-98. [CrossRef]

10. Gonzalez-Casimiro, C.M.; Merino, B.; Casanueva-Alvarez, E.; Postigo-Casado, T.; Camara-Torres, P.; Fernandez-Diaz, C.M.; Leissring, M.A.; Cozar-Castellano, I.; Perdomo, G. Modulation of insulin sensitivity by insulin-degrading enzyme. Biomedicines 2021, 9, 86. [CrossRef]

11. Durham, T.B.; Toth, J.L.; Klimkowski, V.J.; Cao, J.X.; Siesky, A.M.; Alexander-Chacko, J.; Wu, G.Y.; Dixon, J.T.; McGee, J.E.; Wang, Y.; et al. Dual exosite-binding inhibitors of insulin-degrading enzyme challenge its role as the primary mediator of insulin clearance in vivo. J. Biol. Chem. 2015, 290, 20044-20059. [CrossRef] [PubMed]

12. Villa-Perez, P.; Merino, B.; Fernandez-Diaz, C.M.; Cidad, P.; Lobaton, C.D.; Moreno, A.; Muturi, H.T.; Ghadieh, H.E.; Najjar, S.M.; Leissring, M.A.; et al. Liver-specific ablation of insulin-degrading enzyme causes hepatic insulin resistance and glucose intolerance, without affecting insulin clearance in mice. Metabolism 2018, 88, 1-11. [CrossRef]

13. Merino, B.; Fernandez-Diaz, C.M.; Parrado-Fernandez, C.; Gonzalez-Casimiro, C.M.; Postigo-Casado, T.; Lobaton, C.D.; Leissring, M.A.; Cozar-Castellano, I.; Perdomo, G. Hepatic insulin-degrading enzyme regulates glucose and insulin homeostasis in diet-induced obese mice. Metabolism 2020, 113, 154352. [CrossRef] [PubMed]

14. Fernandez-Diaz, C.M.; Merino, B.; Lopez-Acosta, J.F.; Cidad, P.; de la Fuente, M.A.; Lobaton, C.D.; Moreno, A.; Leissring, M.A.; Perdomo, G.; Cozar-Castellano, I. Pancreatic beta-cell-specific deletion of insulin-degrading enzyme leads to dysregulated insulin secretion and beta-cell functional immaturity. Am. J. Physiol. Endocrinol. Metab. 2019, 317, E805-E819. [CrossRef] [PubMed]

15. Steneberg, P.; Bernardo, L.; Edfalk, S.; Lundberg, L.; Backlund, F.; Ostenson, C.G.; Edlund, H. The type 2 diabetes-associated gene ide is required for insulin secretion and suppression of alpha-synuclein levels in beta-cells. Diabetes 2013, 62, 2004-2014. [CrossRef]

16. Mirsky, I.A.; Perisutti, G. Effect of insulinase-inhibitor on hypoglycemic action of insulin. Science 1955, 122, 559-560. [CrossRef]

17. Mirsky, I.A.; Perisutti, G.; Gitelson, S. The role of insulinase in the hypoglycemic response to sulfonylureas. Ann. N. Y. Acad. Sci. 1957, 71, 103-111. [CrossRef]

18. Hersh, L.B. The insulysin (insulin degrading enzyme) enigma. Cell. Mol. Life Sci. 2006, 63, 2432-2434. [CrossRef]

19. Song, E.S.; Rodgers, D.W.; Hersh, L.B. Insulin-degrading enzyme is not secreted from cultured cells. Sci. Rep. 2018, 8, 2335. [CrossRef]

20. Son, S.M.; Cha, M.Y.; Choi, H.; Kang, S.; Choi, H.; Lee, M.S.; Park, S.A.; Mook-Jung, I. Insulin-degrading enzyme secretion from astrocytes is mediated by an autophagy-based unconventional secretory pathway in Alzheimer disease. Autophagy 2016, 12, 784-800. [CrossRef]

21. Son, S.M.; Kang, S.; Choi, H.; Mook-Jung, I. Statins induce insulin-degrading enzyme secretion from astrocytes via an autophagybased unconventional secretory pathway. Mol. Neurodegener. 2015, 10, 56. [CrossRef] [PubMed]

22. Zhao, J.; Li, L.; Leissring, M.A. Insulin-degrading enzyme is exported via an unconventional protein secretion pathway. Mol. Neurodegener. 2009, 4, 4. [CrossRef] [PubMed]

23. Roth, R.A. Insulysin. In Handbook of Proteolytic Enzymes, 2nd ed.; Barrett, A.J., Rawlings, N.D., Woessner, J.F., Eds.; Elsevier: London, UK, 2004; pp. 871-876.

24. Leissring, M.A.; Farris, W.; Wu, X.; Christodoulou, D.C.; Haigis, M.C.; Guarente, L.; Selkoe, D.J. Alternative translation initiation generates a novel isoform of insulin-degrading enzyme targeted to mitochondria. Biochem. J. 2004, 383, 439-446. [CrossRef] [PubMed]

25. Leal, M.C.; Magnani, N.; Villordo, S.; Buslje, C.M.; Evelson, P.; Castano, E.M.; Morelli, L. Transcriptional regulation of insulindegrading enzyme modulates mitochondrial amyloid beta (Abeta) peptide catabolism and functionality. J. Biol. Chem. 2013, 288, 12920-12931. [CrossRef]

26. Morita, M.; Kurochkin, I.V.; Motojima, K.; Goto, S.; Takano, T.; Okamura, S.; Sato, R.; Yokota, S.; Imanaka, T. Insulin-degrading enzyme exists inside of rat liver peroxisomes and degrades oxidized proteins. Cell Struct. Funct. 2000, 25, 309-315. [CrossRef]

27. Neuberger, G.; Maurer-Stroh, S.; Eisenhaber, B.; Hartig, A.; Eisenhaber, F. Motif refinement of the peroxisomal targeting signal 1 and evaluation of taxon-specific differences. J. Mol. Biol. 2003, 328, 567-579. [CrossRef]

28. Neuberger, G.; Maurer-Stroh, S.; Eisenhaber, B.; Hartig, A.; Eisenhaber, F. Prediction of peroxisomal targeting signal 1 containing proteins from amino acid sequence. J. Mol. Biol. 2003, 328, 581-592. [CrossRef]

29. Hamel, F.G.; Mahoney, M.J.; Duckworth, W.C. Degradation of intraendosomal insulin by insulin-degrading enzyme without acidification. Diabetes 1991, 40,436-443. [CrossRef] 
30. Duckworth, W.C.; Hamel, F.G. Cellular and endosomal insulin degradation. Adv. Second. Messenger. Phosphoprot. Res. 1990, 24, 521-528.

31. Clot, J.P.; Janicot, M.; Fouque, F.; Desbuquois, B.; Haumont, P.Y.; Lederer, F. Characterization of insulin degradation products generated in liver endosomes: In vivo and in vitro studies. Mol. Cell. Endocrinol. 1990, 72, 175-185. [CrossRef]

32. Hamel, F.G.; Posner, B.I.; Bergeron, J.J.; Frank, B.H.; Duckworth, W.C. Isolation of insulin degradation products from endosomes derived from intact rat liver. J. Biol. Chem. 1988, 263, 6703-6708. [CrossRef]

33. Duckworth, W.C.; Hamel, F.G.; Liepnieks, J.; Frank, B.H.; Yagil, C.; Rabkin, R. High performance liquid chromatographic analysis of insulin degradation products from a cultured kidney cell line. Endocrinology 1988, 123, 2701-2708. [CrossRef]

34. Li, Q.; Ali, M.A.; Cohen, J.I. Insulin degrading enzyme is a cellular receptor mediating varicella-zoster virus infection and cell-to-cell spread. Cell 2006, 127, 305-316. [CrossRef] [PubMed]

35. Blackard, W.G.; Ludeman, C.; Stillman, J. Role of hepatocyte plasma membrane in insulin degradation. Am. J. Physiol. 1985, 248, E194-E202. [CrossRef]

36. Goldfine, I.D.; Williams, J.A.; Bailey, A.C.; Wong, K.Y.; Iwamoto, Y.; Yokono, K.; Baba, S.; Roth, R.A. Degradation of insulin by isolated mouse pancreatic acini. Evidence for cell surface protease activity. Diabetes 1984, 33, 64-72. [CrossRef] [PubMed]

37. Hammons, G.T.; Smith, R.M.; Jarett, L. Inhibition by bacitracin of rat adipocyte plasma membrane degradation of $125 \mathrm{I}$-insulin is associated with an increase in plasma membrane bound insulin and a potentiation of glucose oxidation by adipocytes. J. Biol. Chem. 1982, 257, 11563-11570. [CrossRef]

38. Yokono, K.; Roth, R.A.; Baba, S. Identification of insulin-degrading enzyme on the surface of cultured human lymphocytes, rat hepatoma cells, and primary cultures of rat hepatocytes. Endocrinology 1982, 111, 1102-1108. [CrossRef] [PubMed]

39. Vekrellis, K.; Ye, Z.; Qiu, W.Q.; Walsh, D.; Hartley, D.; Chesneau, V.; Rosner, M.R.; Selkoe, D.J. Neurons regulate extracellular levels of amyloid beta-protein via proteolysis by insulin-degrading enzyme. J. Neurosci. 2000, 20, 1657-1665. [CrossRef]

40. Mukherjee, A.; Song, E.; Kihiko-Ehmann, M.; Goodman, J.P., Jr.; Pyrek, J.S.; Estus, S.; Hersh, L.B. Insulysin hydrolyzes amyloid beta peptides to products that are neither neurotoxic nor deposit on amyloid plaques. J. Neurosci. 2000, 20, 8745-8749. [CrossRef]

41. Qiu, W.Q.; Walsh, D.M.; Ye, Z.; Vekrellis, K.; Zhang, J.; Podlisny, M.B.; Rosner, M.R.; Safavi, A.; Hersh, L.B.; Selkoe, D.J. Insulindegrading enzyme regulates extracellular levels of amyloid beta-protein by degradation. J. Biol. Chem. 1998, 273, 32730-32738. [CrossRef]

42. Qiu, W.Q.; Ye, Z.; Kholodenko, D.; Seubert, P.; Selkoe, D.J. Degradation of amyloid beta-protein by a metalloprotease secreted by microglia and other neural and non-neural cells. J. Biol. Chem. 1997, 272, 6641-6646. [CrossRef]

43. Suire, C.N.; Leissring, M.A. Cathepsin D: A candidate link between amyloid beta-protein and tauopathy in Alzheimer disease. J. Exp. Neurol. 2021, 2, 10-15. [CrossRef]

44. Suire, C.N.; Abdul-Hay, S.O.; Sahara, T.; Kang, D.; Brizuela, M.K.; Saftig, P.; Dickson, D.W.; Rosenberry, T.L.; Leissring, M.A. Cathepsin D regulates cerebral Abeta42/40 ratios via differential degradation of Abeta42 and Abeta40. Alzheimers Res. Ther. 2020, 12, 80. [CrossRef]

45. Miller, B.C.; Eckman, E.A.; Sambamurti, K.; Dobbs, N.; Chow, K.M.; Eckman, C.B.; Hersh, L.B.; Thiele, D.L. Amyloid-beta peptide levels in brain are inversely correlated with insulysin activity levels in vivo. Proc. Natl. Acad. Sci. USA 2003, 100, 6221-6226. [CrossRef]

46. Leissring, M.A.; Farris, W.; Chang, A.Y.; Walsh, D.M.; Wu, X.; Sun, X.; Frosch, M.P.; Selkoe, D.J. Enhanced proteolysis of beta-amyloid in APP transgenic mice prevents plaque formation, secondary pathology, and premature death. Neuron 2003, 40, 1087-1093. [CrossRef]

47. Bulloj, A.; Leal, M.C.; Xu, H.; Castano, E.M.; Morelli, L. Insulin-degrading enzyme sorting in exosomes: A secretory pathway for a key brain amyloid-beta degrading protease. J. Alzheimers Dis. 2010, 19, 79-95. [CrossRef] [PubMed]

48. DelleDonne, A.; Kouri, N.; Reinstatler, L.; Sahara, T.; Li, L.; Zhao, J.; Dickson, D.W.; Ertekin-Taner, N.; Leissring, M.A. Development of monoclonal antibodies and quantitative ELISAs targeting insulin-degrading enzyme. Mol. Neurodegener. 2009, 4, 39. [CrossRef] [PubMed]

49. Adamek, R.N.; Suire, C.N.; Stokes, R.W.; Brizuela, M.K.; Cohen, S.M.; Leissring, M.A. Hydroxypyridinethione inhibitors of human insulin-degrading enzyme. ChemMedChem 2021, 16, 1775-1787. [CrossRef]

50. Maianti, J.P.; Tan, G.A.; Vetere, A.; Welsh, A.J.; Wagner, B.K.; Seeliger, M.A.; Liu, D.R. Substrate-selective inhibitors that reprogram the activity of insulin-degrading enzyme. Nat. Chem. Biol. 2019, 15, 565-574. [CrossRef]

51. Suire, C.N.; Nainar, S.; Fazio, M.; Kreutzer, A.G.; Paymozd-Yazdi, T.; Topper, C.L.; Thompson, C.R.; Leissring, M.A. Peptidic inhibitors of insulin-degrading enzyme with potential for dermatological applications discovered via phage display. PLoS ONE 2018, 13, e0193101. [CrossRef]

52. Abdul-Hay, S.O.; Bannister, T.D.; Wang, H.; Cameron, M.D.; Caulfield, T.R.; Masson, A.; Bertrand, J.; Howard, E.A.; McGuire, M.P.; Crisafulli, U.; et al. Selective targeting of extracellular insulin-degrading enzyme by quasi-irreversible thiol-modifying inhibitors. ACS Chem. Biol. 2015, 10, 2716-2724. [CrossRef]

53. Liu, Y.; Guan, H.; Beckett, T.L.; Juliano, M.A.; Juliano, L.; Song, E.S.; Chow, K.M.; Murphy, M.P.; Hersh, L.B. In vitro and in vivo degradation of Abeta peptide by peptidases coupled to erythrocytes. Peptides 2007, 28, 2348-2355. [CrossRef] [PubMed]

54. Li, H.; Zhu, H.; Wallack, M.; Mwamburi, M.; Abdul-Hay, S.O.; Leissring, M.A.; Qiu, W.Q. Age and its association with low insulin and high amyloid-beta peptides in blood. J. Alzheimers Dis. 2015, 49, 129-137. [CrossRef] [PubMed] 
55. Demidowich, A.P.; Levine, J.A.; Brady, S.M.; Johnson, C.D.; Soldin, S.J.; Yanovski, J.A. Bacitracin attenuates haemolysis-induced insulin degradation during insulin sensitivity testing: Repurposing an old drug for use in metabolic research. Diabetes Obes. Metab. 2020, 22, 1469-1473. [CrossRef]

56. Im, H.; Manolopoulou, M.; Malito, E.; Shen, Y.; Zhao, J.; Neant-Fery, M.; Sun, C.Y.; Meredith, S.C.; Sisodia, S.S.; Leissring, M.A.; et al. Structure of substrate-free human insulin-degrading enzyme (IDE) and biophysical analysis of ATP-induced conformational switch of IDE. J. Biol. Chem. 2007, 282, 25453-25463. [CrossRef]

57. Tang, W.J. Targeting insulin-degrading enzyme to treat type 2 diabetes mellitus. Trends. Endocrinol. Metab. 2016, 27, 24-34. [CrossRef] [PubMed]

58. Zhang, Z.; Liang, W.G.; Bailey, L.J.; Tan, Y.Z.; Wei, H.; Wang, A.; Farcasanu, M.; Woods, V.A.; McCord, L.A.; Lee, D.; et al. Ensemble cryoEM elucidates the mechanism of insulin capture and degradation by human insulin degrading enzyme. Elife 2018, 7, e33572. [CrossRef] [PubMed]

59. Neant-Fery, M.; Garcia-Ordonez, R.D.; Logan, T.P.; Selkoe, D.J.; Li, L.; Reinstatler, L.; Leissring, M.A. Molecular basis for the thiol sensitivity of insulin-degrading enzyme. Proc. Natl. Acad. Sci. USA 2008, 105, 9582-9587. [CrossRef]

60. Misbin, R.I.; Almira, E.C. Degradation of insulin and insulin-like growth factors by enzyme purified from human erythrocytes. Comparison of degradation products observed with A14- and B26-[125I]monoiodoinsulin. Diabetes 1989, 38, 152-158. [CrossRef] [PubMed]

61. Roth, R.A.; Mesirow, M.L.; Yokono, K.; Baba, S. Degradation of insulin-like growth factors I and II by a human insulin degrading enzyme. Endocr. Res. 1984, 10, 101-112. [CrossRef] [PubMed]

62. Guo, Q.; Manolopoulou, M.; Bian, Y.; Schilling, A.B.; Tang, W.J. Molecular basis for the recognition and cleavages of IGF-II, TGF-alpha, and amylin by human insulin-degrading enzyme. J. Mol. Biol. 2010, 395, 430-443. [CrossRef]

63. Cabrol, C.; Huzarska, M.A.; Dinolfo, C.; Rodriguez, M.C.; Reinstatler, L.; Ni, J.; Yeh, L.-A.; Cuny, G.D.; Stein, R.L.; Selkoe, D.J.; et al. Small-molecule activators of insulin-degrading enzyme discovered through high-throughput compound screening. PLoS ONE 2009, 4, e5274. [CrossRef] [PubMed]

64. Llovera, R.E.; de Tullio, M.; Alonso, L.G.; Leissring, M.A.; Kaufman, S.B.; Roher, A.E.; de Prat Gay, G.; Morelli, L.; Castano, E.M. The catalytic domain of insulin-degrading enzyme forms a denaturant-resistant complex with amyloid beta peptide: Implications for Alzheimer disease pathogenesis. J. Biol. Chem. 2008, 283, 17039-17048. [CrossRef] [PubMed]

65. De Tullio, M.B.; Castelletto, V.; Hamley, I.W.; Martino Adami, P.V.; Morelli, L.; Castano, E.M. Proteolytically inactive insulindegrading enzyme inhibits amyloid formation yielding non-neurotoxic abeta peptide aggregates. PLoS ONE 2013,8 , e59113. [CrossRef] [PubMed]

66. Sharma, S.K.; Chorell, E.; Wittung-Stafshede, P. Insulin-degrading enzyme is activated by the C-terminus of alpha-synuclein. Biochem. Biophys. Res. Commun. 2015, 466, 192-195. [CrossRef]

67. Sharma, S.K.; Chorell, E.; Steneberg, P.; Vernersson-Lindahl, E.; Edlund, H.; Wittung-Stafshede, P. Insulin-degrading enzyme prevents alpha-synuclein fibril formation in a nonproteolytical manner. Sci. Rep. 2015, 5, 12531. [CrossRef]

68. Song, E.S.; Rodgers, D.W.; Hersh, L.B. A monomeric variant of insulin degrading enzyme (IDE) loses its regulatory properties PLOS ONE 2010, 5, e9719. [CrossRef]

69. Manolopoulou, M.; Guo, Q.; Malito, E.; Schilling, A.B.; Tang, W.J. Molecular basis of catalytic chamber-assisted unfolding and cleavage of human insulin by human insulin-degrading enzyme. J. Biol. Chem. 2009, 284, 14177-14188. [CrossRef]

70. Harada, S.; Smith, R.M.; Jarett, L. Mechanisms of nuclear translocation of insulin. Cell Biochem. Biophys. 1999, 31, 307-319. [CrossRef]

71. Harada, S.; Smith, R.M.; Hu, D.Q.; Jarett, L. Dexamethasone inhibits insulin binding to insulin-degrading enzyme and cytosolic insulin-binding protein p82. Biochem. Biophys. Res. Commun. 1996, 218, 154-158. [CrossRef]

72. Shah, N.; Zhang, S.; Harada, S.; Smith, R.M.; Jarett, L. Electron microscopic visualization of insulin translocation into the cytoplasm and nuclei of intact H35 hepatoma cells using covalently linked Nanogold-insulin. Endocrinology 1995, 136, 2825-2835. [CrossRef]

73. Harada, S.; Smith, R.M.; Smith, J.A.; Shah, N.; Jarett, L. Demonstration of specific insulin binding to cytosolic proteins in H35 hepatoma cells, rat liver and skeletal muscle. Biochem. J. 1995, 306 Pt 1, 21-28. [CrossRef]

74. Harada, S.; Smith, R.M.; Jarett, L. 1,10-Phenanthroline increases nuclear accumulation of insulin in response to inhibiting insulin degradation but has a biphasic effect on insulin's ability to increase mRNA levels. DNA Cell. Biol. 1994, 13, 487-493. [CrossRef]

75. Harada, S.; Smith, R.M.; Smith, J.A.; Jarett, L. Inhibition of insulin-degrading enzyme increases translocation of insulin to the nucleus in H35 rat hepatoma cells: Evidence of a cytosolic pathway. Endocrinology 1993, 132, 2293-2298. [CrossRef]

76. Malito, E.; Hulse, R.E.; Tang, W.J. Amyloid beta-degrading cryptidases: Insulin degrading enzyme, presequence peptidase, and neprilysin. Cell. Mol. Life Sci. 2008, 65, 2574-2585. [CrossRef]

77. Malito, E.; Ralat, L.A.; Manolopoulou, M.; Tsay, J.L.; Wadlington, N.L.; Tang, W.J. Molecular bases for the recognition of short peptide substrates and cysteine-directed modifications of human insulin-degrading enzyme. Biochemistry 2008, 47, 12822-12834. [CrossRef]

78. Song, E.S.; Juliano, M.A.; Juliano, L.; Hersh, L.B. Substrate activation of insulin-degrading enzyme (insulysin). A potential target for drug development. J. Biol. Chem. 2003, 278, 49789-49794. [CrossRef]

79. Suire, C.N.; Brizuela, M.K.; Leissring, M.A. Quantitative, high-throughput assays for proteolytic degradation of amylin. Methods Protoc. 2020, 3, 81. [CrossRef] [PubMed] 
80. Suire, C.N.; Lane, S.; Leissring, M.A. Development and characterization of quantitative, high-throughput-compatible assays for proteolytic degradation of glucagon. SLAS Discov. 2018, 23, 1060-1069. [CrossRef] [PubMed]

81. Leissring, M.A.; Lu, A.; Condron, M.M.; Teplow, D.B.; Stein, R.L.; Farris, W.; Selkoe, D.J. Kinetics of amyloid beta-protein degradation determined by novel fluorescence- and fluorescence polarization-based assays. J. Biol. Chem. 2003, 278, 37314-37320. [CrossRef] [PubMed]

82. Kupfer, S.R.; Wilson, E.M.; French, F.S. Androgen and glucocorticoid receptors interact with insulin degrading enzyme. J. Biol. Chem. 1994, 269, 20622-20628. [CrossRef]

83. Bennett, R.G.; Fawcett, J.; Kruer, M.C.; Duckworth, W.C.; Hamel, F.G. Insulin inhibition of the proteasome is dependent on degradation of insulin by insulin-degrading enzyme. J. Endocrinol. 2003, 177, 399-405. [CrossRef]

84. Hamel, F.G.; Bennett, R.G.; Duckworth, W.C. Regulation of multicatalytic enzyme activity by insulin and the insulin-degrading enzyme. Endocrinology 1998, 139, 4061-4066. [CrossRef]

85. Duckworth, W.C.; Bennett, R.G.; Hamel, F.G. Insulin acts intracellularly on proteasomes through insulin-degrading enzyme. Biochem. Biophys. Res. Commun. 1998, 244, 390-394. [CrossRef] [PubMed]

86. Song, E.S.; Jang, H.; Guo, H.F.; Juliano, M.A.; Juliano, L.; Morris, A.J.; Galperin, E.; Rodgers, D.W.; Hersh, L.B. Inositol phosphates and phosphoinositides activate insulin-degrading enzyme, while phosphoinositides also mediate binding to endosomes. Proc. Natl. Acad. Sci. USA 2017, 114, E2826-E2835. [CrossRef] [PubMed]

87. Leissring, M.A.; Malito, E.; Hedouin, S.; Reinstatler, L.; Sahara, T.; Abdul-Hay, S.O.; Choudhry, S.; Maharvi, G.M.; Fauq, A.H.; Huzarska, M.; et al. Designed inhibitors of insulin-degrading enzyme regulate the catabolism and activity of insulin. PLoS ONE 2010, 5, e10504. [CrossRef]

88. Charton, J.; Gauriot, M.; Guo, Q.; Hennuyer, N.; Marechal, X.; Dumont, J.; Hamdane, M.; Pottiez, V.; Landry, V.; Sperandio, O.; et al. Imidazole-derived 2-[N-carbamoylmethyl-alkylamino]acetic acids, substrate-dependent modulators of insulin-degrading enzyme in amyloid-beta hydrolysis. Eur. J. Med. Chem. 2014, 79, 184-193. [CrossRef]

89. Deprez-Poulain, R.; Hennuyer, N.; Bosc, D.; Liang, W.G.; Enee, E.; Marechal, X.; Charton, J.; Totobenazara, J.; Berte, G.; Jahklal, J.; et al. Catalytic site inhibition of insulin-degrading enzyme by a small molecule induces glucose intolerance in mice. Nat. Commun. 2015, 6, 8250. [CrossRef] [PubMed]

90. Bannister, T.D.; Wang, H.; Abdul-Hay, S.O.; Masson, A.; Madoux, F.; Ferguson, J.; Mercer, B.A.; Schurer, S.; Zuhl, A.; Cravatt, B.F.; et al. ML345: A small-molecule inhibitor of the insulin-degrading enzyme (IDE). In Probe Reports from the NIH Molecular Libraries Program; National Center for Biotechnology Information (US): Bethesda, MD, USA, 2014.

91. Leissring, M.A. Abeta-degrading proteases: Therapeutic potential in Alzheimer disease. CNS Drugs 2016, 30, 667-675. [CrossRef]

92. Abdul-Hay, S.O.; Lane, A.L.; Caulfield, T.R.; Claussin, C.; Bertrand, J.; Masson, A.; Choudhry, S.; Fauq, A.H.; Maharvi, G.M.; Leissring, M.A. Optimization of peptide hydroxamate inhibitors of insulin-degrading enzyme reveals marked substrate-selectivity. J. Med. Chem. 2013, 56, 2246-2255. [CrossRef]

93. Sahoo, B.R.; Panda, P.K.; Liang, W.; Tang, W.J.; Ahuja, R.; Ramamoorthy, A. Degradation of alzheimer's amyloid-beta by a catalytically inactive insulin-degrading enzyme. J. Mol. Biol. 2021, 433, 166993. [CrossRef]

94. Duckworth, W.C.; Fawcett, J.; Reddy, S.; Page, J.C. Insulin-degrading activity in wound fluid. J. Clin. Endocrinol. Metab. 2004, 89, 847-851. [CrossRef] [PubMed]

95. Shearer, J.D.; Coulter, C.F.; Engeland, W.C.; Roth, R.A.; Caldwell, M.D. Insulin is degraded extracellularly in wounds by insulin-degrading enzyme (EC 3.4.24.56). Am. J. Physiol. 1997, 273, E657-E664. [CrossRef] [PubMed]

96. Rund, C.R. Non-conventional topical therapies for wound care. Ostomy/Wound Manag. 1996, 42, 18-20.

97. Hsu, P.D.; Lander, E.S.; Zhang, F. Development and applications of CRISPR-Cas9 for genome engineering. Cell 2014, 157, 1262-1278. [CrossRef] 